\title{
Evaluation of geographical indication for the clay handicraft from a city in the Northeast of Brazil
}

\author{
Avaliação de indicação geográfica para o artesanato em barro de \\ uma cidade do Nordeste do Brasil
}

\author{
M. T. Souza ${ }^{1}$; B. L. P. Santos 2 ; D. S. Ruzene ${ }^{1,2}$; C. R. de Vasconcelos ${ }^{1,3} ;$ R. \\ De-Bortoli ${ }^{3}$, D. P. Silva ${ }^{1,2,3^{*}}$ \\ ${ }^{1}$ Center for Exact Sciences and Technology, Federal University of Sergipe/UFS, 49100-000, São Cristóvão-SE, Brazil \\ ${ }^{2}$ Northeastern Biotechnology Network - RENORBIO/UFS, 49100-000, São Cristóvão-SE, Brazil \\ ${ }^{3}$ Graduate Program in Intellectual Property Science - PPGPI/UFS, 49100-000, São Cristóvão-SE, Brazil
}

*silvadp@hotmail.com

(Recebido em 26 de agosto de 2020; aceito em 26 de fevereiro de 2021)

\begin{abstract}
Geographical indications (GIs) can provide quality perception to a product by recognizing its unique characteristics, which creates the expectation that the registration of a GI is associated with its regional economic development. According to the literature, there are two types of GI: appellation of origin (AO) and indication of source (IS). The present study aimed to evaluate the best practice for obtaining an IS for the clay handicrafts produced in the municipality of Santana do São Francisco, in the northeast region of Brazil. Applied research, with a qualitative structure, was the methodology used to identify and select the ideal agents that potentiate the gains resulting from the GI. The evaluation was based on the methodology defined by the Ministry of Agriculture, Livestock and Supply of Brazil (Mapa), adapted for the qualification of agents able to carry out the necessary actions for the recognition process. The results showed that the Association of Artisans and the Brazilian Micro and Small Business Support Service (Sebrae) could act as the requesting and support entities, respectively, since both fulfill the requirements to work in favor of obtaining an indication of source in Santana do São Francisco.
\end{abstract}

Keywords: clay handicraft, geographical indication, socioeconomic development

A Indicação Geográfica (IG) pode conferir uma percepção de qualidade a um produto ao reconhecer suas características únicas, o que cria a expectativa de que o registro de uma IG traga desenvolvimento econômico da região. Assim, o presente trabalho objetivou avaliar a melhor prática para obtenção de Indicação Geográfica por procedência para o artesanato em barro produzido no município sergipano de Santana do São Francisco, região nordeste brasileira. Foram identificados e selecionados os agentes que potencializariam os ganhos advindos desse reconhecimento. A pesquisa aplicada, de estrutura qualitativa, foi a metodologia utilizada para identificar e selecionar os agentes ideais que potencializassem os ganhos advindos da IG. A avaliação baseou-se na metodologia definida pelo Ministério da Agricultura, Pecuária e Abastecimento (Mapa), adaptada para qualificação dos agentes aptos a realizar as ações necessárias ao processo de reconhecimento. Os resultados demonstraram que a Associação de Artesãos do município e o Serviço Brasileiro de Apoio às Micro e Pequenas Empresas (Sebrae) poderiam atuar como as entidades solicitadora e de apoio, respectivamente, uma vez que ambos preenchem os requisitos necessários para trabalhar em prol da obtenção de uma indicação geográfica na modalidade de procedência.

Palavras-chave: artesanato em barro, indicação geográfica, desenvolvimento socioeconômico

\section{INTRODUCTION}

In addition to being a legal protection instrument, the Geographical Indication (GI) acts as a competitive differential by recognizing that regional specificities attribute unique characteristics to a given product, allowing it to be differentiated from its competitors [1-3]. When analyzing the aspects related to this valorization, Belletti et al. (2017) [4] established two key characteristics of a GI product, such as (i) anthropic and physical resources were used in its production or marketing process and (ii) collective efforts and historical character granted its regional identity.

Historically, the growth in the use of GIs has been associated with commercial interests of expansion and preservation of sales, as port wine and champagne, respectively [5]. This is because in the evaluation of a production chain, the GIs give the consumer a perception of a higher added 
value of a product compared to its normal peers, allowing the search for better prices and enabling a greater volume of production [6]. In Brazil, the regulation associated with GIs was consolidated by the Industrial Property Law number 9279/96, which defines GI as the set of distinctive signs for which legal protection is granted in respect of geographical regions that are recognized as the production pole of a product or service [7]. The enforcement of rules related to industrial property is subject to the National Institute of Industrial Property (INPI) [8].

Both appellations of origin (AO) and indications of source (IS) are ways of classifying a product's geographical indication. According to the literature, indication of source defines the place where a product has its differential recognized by the cultural aspect involved in its mode of production, resulting in a distinction that can lead to greater added value [9]. The World Intellectual Property Organization (WIPO) characterizes indications of source as an indication that provides to the consumer the geographic location where a product was produced or processed [10]. Unlike the concept adopted by the European Union, Brazilian regulation allows IS registrations to be granted to products of any nature, including services, beverages, and agricultural products [11].

The clay handicrafts, manufactured in the Santana do São Francisco, located in the interior of Sergipe (10 $\left.17^{\prime} 16.20^{\prime \prime} \mathrm{S}, 36^{\circ} 36^{\prime} 16.79^{\prime \prime} \mathrm{W}\right)$, perfectly inserts in the context presented. Although the region was initially populated by Dutch people in the 17th century, records of its evolution appeared only in the 20th century, when Captain Belarmino Gomes da Silva Dias founded Carrapicho Farm (Fazenda Carrapicho). The first artifacts made of clay in the region arose due to the need for farm employees to obtain domestic utensils for their own use, but today, the sale of ceramics is one of the main economic activities in the region, generating income for several families [12].

Even though the first artifacts had a character of practical and domestic utility, this did not prevent the emergence of works that represented symbols of the daily life of the artisans, who started to express themselves artistically and culturally, as a reflection of their cultural identity. On this point, Sai Deepak (2008) [13] observed that traditional handicrafts have distinct characteristics from other art forms as their emergence was connected to the basic human needs, while other types of cultural manifestation, such as music and art, are examples of intellectual and social development.

A critical aspect observed is the connotation of handicrafts' production as a form of collective memory. For Halbwachs (1990) [14], this memory is formed through a collective social construction where individual knowledge is perpetuated on a common basis related to memories to the past, being limited in time and space. This spatial limitation reinforces the handicraft production as a way the territorial identity, for which Haesbaert (1997) [15] states that beyond the practical ordering of space, the territory involves a symbolic dimension attributed by social groups to the place where they live as a form of identity and appropriation.

In the last survey carried out in Brazilian territory, realized in 2018, it was found that only $6.8 \%$ of the population of Santana do São Francisco has a formal contract job, demonstrating the strong presence of informal activities as the only source of income. Santana do São Francisco has a Municipal Human Development Index (MHDI) of 0.590 (collected in 2010) and occupies the fifth worst position in the municipalities of the state of Sergipe in the ranking of Gross Domestic Product (GDP) per capita (R\$ 8917.56 or, approximately, US\$ 1660 considering the current dollar quotation) [12]. This data reinforces the importance of seeking alternatives that allow the valorization of regional commercial activities in order to rescue the population's income. There is a need for an organized implementation of initiatives aimed at improving the collective management of production, as well as strengthening the institutional environment to mitigate the risks of failure and waste of resources. Despite the creation in 1977 of the Handmade Cooperative of Carrapicho Ceramics (in Portuguese Cooperativa Artesanal de Cerâmica de Carrapicho), whose objective was to encourage and boost the production of handicrafts, the cooperative ended up failing due to the discredit of the cooperative members [12].

The production of handicrafts has great tourist and commercial potential, which can be developed through the differentiation, guarantee, and recognition of a traditional quality product. All these advantages can be obtained with the registration of the geographical indication addressed presented in this study. That way, the geographical characteristics of the region bordering the São Francisco River, one of the main rivers in South America, combined with the handicraft production pole, signal a promising path for the municipality's economic development. However, there are 
some limitations involved in the process related to the capacity of the agents involved in promoting the awareness and recognition of customers $[16,17]$. Within this context, this work sought to describe the procedural instruction conditions for requesting an indication of source for the clay handicrafts produced in the riverside municipality of Santana do São Francisco.

\section{MATERIAL AND METHODS}

The qualitative analysis was initiated by the bibliographic survey of the requirements necessary to obtain the indication of source, as well as the complementary practices defined in the literature as promoters of positive economic results. Then, the feasibility of obtaining the IS for the handicrafts produced in Santana do São Francisco was verified through the observation of the agents involved in the process regarding their willingness and ability to meet pre-established requirements by the Ministry of Agriculture, Livestock and Supply of Brazil (Mapa). Such requirements are associated with economic return and regional development. According to Pellin (2018) [18], this methodology generates the highest capacity to obtain results, being composed of three stages, as shown in Table 1. On the other hand, the expected characteristics for regional, mediator, and fomentation agents for a GI registration were described in Table 2.

Table 1: Stages to obtain the Mapa geographical indication.

\begin{tabular}{cl}
\hline Stage & \multicolumn{1}{c}{ Description } \\
\hline Prospection & $\begin{array}{l}\text { Identification of the agents involved in the GI recognition process, } \\
\text { supporting, and benefiting from the achievement. Following the construction } \\
\text { of a network that stimulates the development of the region from its territorial } \\
\text { assets } \\
\text { Awareness of the involved agents regarding the collective management of } \\
\text { the products recognized by GI, involving the various aspects of its } \\
\text { production and commercialization. Training and awareness-raising activities } \\
\text { are also developed so that individual ambitions do not harm the overall result }\end{array}$ \\
$\begin{array}{c}\text { Organization and andination } \\
\text { promotion }\end{array}$ & $\begin{array}{l}\text { Carried out after obtaining the GI, it aims to give continuity and promote } \\
\text { participation in the product market with its new identity, involving marketing } \\
\text { and business actions to develop distribution channels }\end{array}$
\end{tabular}

Source: Adapted from Pellin (2018) [18]. 
Table 2: Agents and their expected characteristics for obtaining the geographical indication.

\section{Types of agents $\quad$ Expected characteristics}

Regional Legal aspect: able to meet the criteria established by the INPI to obtain the GI (requesting entity) Economic aspect: able to promote an organization that enables regional development through the GI

Legal aspect: able to mediate and represent the regional agent, compiling the

Mediator necessary information, being responsible for the process with the INPI

(supporting entity) Economic aspect: able to carry out the training of the regional agent, establishing the collective consciousness necessary to achieve results related to GI

Legal aspect: representative of the regional agent to promote the product and

Fomentation (supporting entity) participate in events

Economic aspect: able to work with the distribution and sales channels, consolidating the new collective identity represented by GI to guarantee the permanence of the results

Source: Authors' own elaboration.

The information present in the literature about handicrafts produced in the region, such as its relationship with the identity, culture, and social aspects of the area, addressed by Mendonça (2002) [19] and Gramacho et al. (2017) [20], as well as the analysis of the local productive arrangement, carried out by Matos and Melo (2007) [21], were considered sufficient to demonstrate the recognition of the differential and the cultural aspects involved in the production mode, necessary to obtain the indication of source (IS). The following items performed a bibliographic evaluation to select and analyze the potential of institutions as requesting agents for registration of a successful IS in Santana do São Francisco. It was also assessed the viability and predisposition of organizations to participate in both the geographical indication process and adhere to the practices necessary to achieve regional development.

\section{RESULTS AND DISCUSSION}

With the data provided by the INPI, it was possible to analyze the scenario in Santana do São Francisco to obtain an indication of source of the clay handicrafts and related activities [22]. Table 3 describes the IS grouped according to their nature but given the prominence of some products such as cheese, wine, and coffee, these items were categorized separately. The success rates associated with IS registration requests for products of a similar nature were shown in Figure 1. During the search, it was found that only one of the thirteen applications for ISs requested for handcrafted items was rejected, indicating an excellent success rate for the recognition of this type of production and signaling a favorable scenario for obtaining protection to the clay handicrafts of the region. 
Table 3: Categorization of different products and services according to their nature.

\begin{tabular}{|c|c|}
\hline Categories & Products and services \\
\hline Agricultural & $\begin{array}{l}\text { Pineapple; saffron; cotton; processed cotton; cocoa almonds (Theobroma Cacao L.); } \\
\text { cocoa; cocoa in almonds; yerba mate; flour; cassava flour; guava; Guaraná (Paullinia } \\
\text { cupana Var. Sorbilis); yam; melon; black pepper; pink pepper (Schinus } \\
\text { terebinthifolius) in natura and processed; naturally colored cotton textiles }\end{array}$ \\
\hline $\begin{array}{l}\text { Handicrafts and } \\
\text { manual/industrial } \\
\text { production }\end{array}$ & $\begin{array}{l}\text { Capim Dourado handicrafts; Cutlery articles; Embroidery; Filet Embroidery; Seridó } \\
\text { embroidery; Footwear; Artistic ceramics; Handmade silver jewelry; Precious Pedro II } \\
\text { opal and Pedro II handmade opal jewelry; Clay pots; Tin craft pieces; Lace in Needles; } \\
\text { Renaissance Lace }\end{array}$ \\
\hline Drinks & Sugarcane brandy; Cachaça; Cajuína \\
\hline Coffee & $\begin{array}{l}\text { Coffee; Green coffee beans, roasted and ground industrialized coffee; Raw, processed, } \\
\text { roasted, and roasted and ground coffee beans; Green Coffee and Roasted and Ground } \\
\text { Coffee; Green coffee beans and industrialized beans and or ground; Green coffee beans } \\
\text { (Coffea arabica) }\end{array}$ \\
\hline Culinary items & $\begin{array}{l}\text { Banana candy; cookie; artisanal chocolate; derivatives of jabuticaba: liquor, jelly, } \\
\text { sauce, candied peel and jam; traditional sweets and fruit confectionery; whipped } \\
\text { molasses and drained molasses }\end{array}$ \\
\hline Minerals & $\begin{array}{l}\text { Mineral and soda waters, extraction/exploration of mineral water; knitwear industry } \\
\text { and trade; handicrafts; hotels, resorts and tourism; marble }\end{array}$ \\
\hline Livestock & $\begin{array}{l}\text { Bovine meat and its derivatives; sun dried meat; finished leather; sausage; honey; honey } \\
\text { bee Ápis Melífera Escutelata (Apis Africanized); honey bee Jataí (Tetragonisca } \\
\text { Angustula); ornamental fish; Socol }\end{array}$ \\
\hline Electronic products & Electronic and telecommunication equipment \\
\hline Cheese & Cheese; Canastra Cheese; Artisanal cheese from the mountains \\
\hline Services & $\begin{array}{l}\text { Bakery and snack bar; bakery, confectionery and pastry; production of cachaça brandy } \\
\text { and bluish compound brandy; information and communication technology service } \\
\text { through development, maintenance and support; gastronomic service of barreado; } \\
\text { auxiliary services to the trade of bottled mineral and soda waters }\end{array}$ \\
\hline Wine & $\begin{array}{l}\text { White dry wine, white soft wine or demi-sec, white light dry wine, white soft wine or } \\
\text { demi-sec, brut sparkling wine, or demi-sec obtained by the Champenoise method; brut } \\
\text { or demi-sec sparkling wine obtained by the Chamat method; liqueur wine; white } \\
\text { Moscatel fine wine, sparkling Moscatel wine, semi-sparkling wine, Moscatel liqueur } \\
\text { wine, Mistela Moscatel; light red wine, fine sparkling wine; white and sparkling wine; } \\
\text { wines; wines and sparkling wines; red, white and sparkling wines }\end{array}$ \\
\hline
\end{tabular}

Source: Adapted from INPI (2020) [22]. 

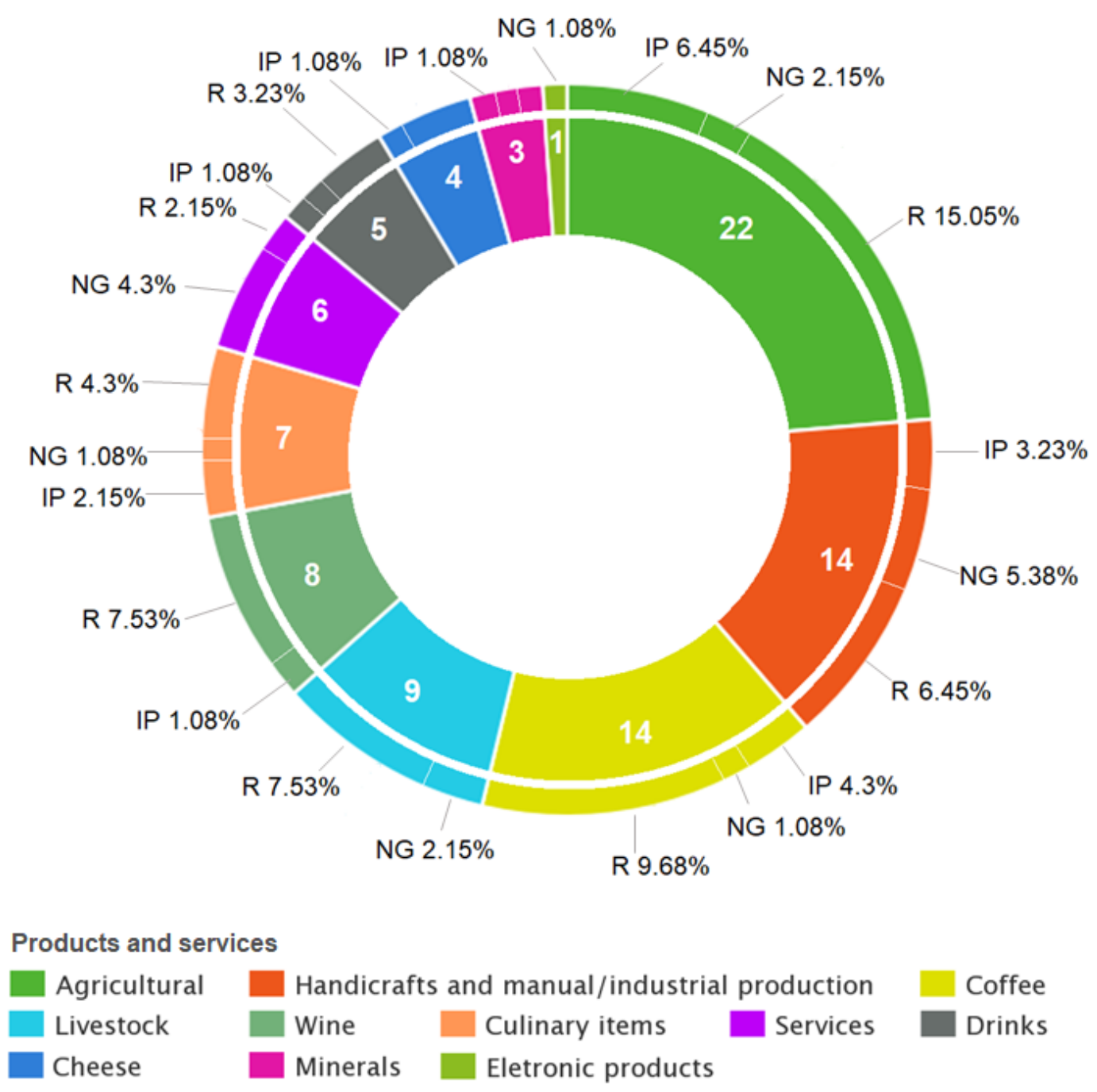

Figure 1: Indications of source organized according to category and status - not granted (NG), in progress $(I P)$ and registration $(R)$ - for the different products and services listed in Table 3. Source: Authors' own elaboration based on data from INPI (2020) [22].

In the sequence, the agencies and entities were analyzed according to their history in the promotion of the indications of source and in other actions involving cultural development in different cities of Sergipe. The results obtained were presented in Table 4.

Table 4: Sergipe institutions and entities classified according to the type of agent for IS registration.

Agent Institutions and entities

\begin{tabular}{|c|c|}
\hline Regional & $\begin{array}{l}\text { Artisans and organizations involved in the production of handicrafts in } \\
\text { Santana do São Francisco }\end{array}$ \\
\hline Mediator & $\begin{array}{l}\text { Sebrae; Secretary of Culture of the State of Sergipe; Federal University } \\
\text { of Sergipe; Tiradentes University }\end{array}$ \\
\hline Promotion & $\begin{array}{l}\text { Sebrae; Secretary of Culture of the State of Sergipe; Santana do São } \\
\text { Francisco City Hall }\end{array}$ \\
\hline
\end{tabular}

Source: Authors' own elaboration. 
The data also indicated the necessary characteristics for a regional agent to act for the artisans of Santana do São Francisco and the role of Sebrae as the more qualified and prepared entity to act as a mediator and promoter. Nowadays, the artisans are represented by an organization nominated as the Association of Artisans (in Portuguese Associação de Artesãos).

\subsection{Requesting entity}

The establishment of the Association of Artisans as a regional agent in Santana do São Francisco needs to be ensured in the entity's ability to meet the legal criteria defined by the INPI to obtain the GI. The association must be able to act in promoting regional development, gathering and defending the interests of artisans. Another aspect favorable to the process of recognition of the GI refers to the ability to precisely define the territorial limits of the municipality and the notorious differential of its products, which are regionally recognized [11].

Few references in the literature indicate the capacity or inability to perform this role, except for the observations made by Matos and Melo (2007) [21], who presented the difficulty of integrated action of the entire production chain of handicrafts around a cooperative or association, due to problems occurred in past experiences. Even though the Association of Artisans does not yet represent the entire class, its role as a regional agent cannot be discarded. Although at least one association is necessary to represent the artisans with the INPI in order to request an is, the request is not unfeasible just because this association is not the only representative of the producers [23]. It is important to emphasize that the existence of an association does not represent a loss of autonomy for the individual producer, but rather the search for cooperation and reduction of global costs, putting together a more competitive structure in the face of market demands. Thus, the Association of Artisans was considered a good choice of regional agent to enable and develop the actions expected for Santana do São Francisco.

Cities near Santana do São Francisco with superior economic development, such as Penedo (located on the left of the São Francisco River), Propriá, and Neópolis (situated on the right of the river) can be encouraged to provide the necessary financial and logistical support for the geographical indication. This type of support is justified by the offer of mutual benefits resulting from the growth of handicrafts in the region, since certification can stimulate the growth of other profitable activities, such as tourism. GIs commonly lead to the development of other segments indirectly. When analyzing the recognition of the IS of the Goethe Grape Valleys in Santa Catarina, Vieira (2015) [24] attested the development of complementary activities such as wine tourism and the preservation of the local identity.

\subsection{Supporting entities}

The information available in the literature indicates an intense participation of public and private entities, such as universities and government agencies, in guiding and coordinating the processes for obtaining GIs. These entities were responsible for compiling the fundamental information to enter the request at the INPI, promoting actions capable of establishing the necessary conditions for obtaining and consolidating results from the recognition of the geographical indication $[11,18$, 23].

Figure 2 presents the data obtained after the consultation carried out in indications of source requested until 2019, combined with all the information obtained in the scientific literature and in the press releases on GIs. It can be noticed an intense participation of Sebrae in all the five Brazilian regions, with minor performance of other entities. 


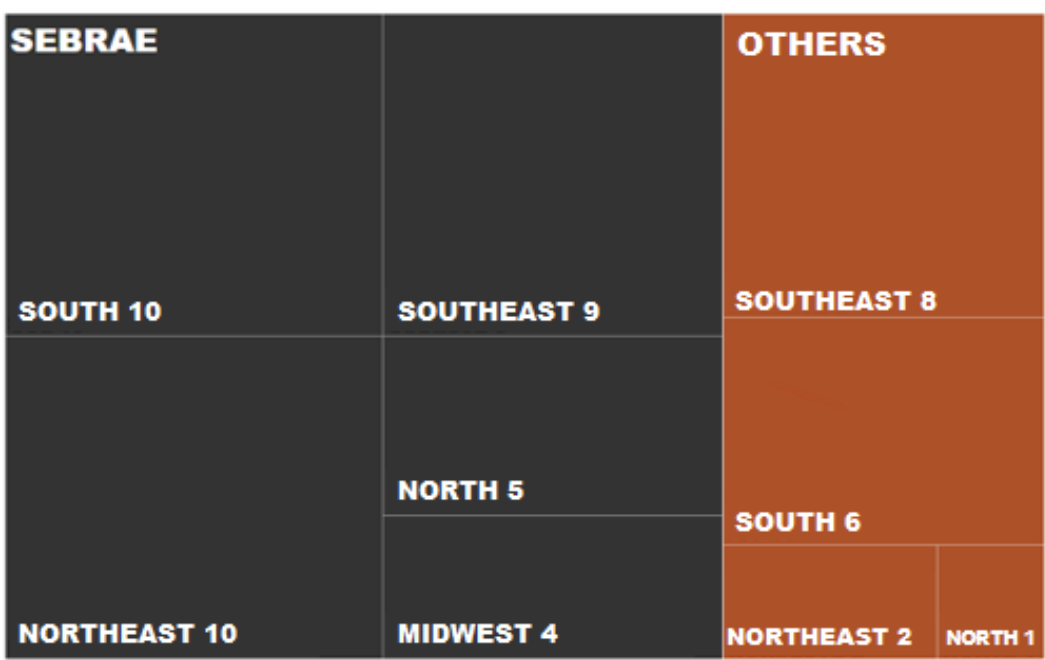

Figure 2: Involvement of Sebrae and other entities in the process of indications of source in different Brazilian regions. Source: Authors' own elaboration.

As regards the development of geographical indications, Sebrae's operating methodology is described as a set of procedures divided into stages of awareness and training [18]. The agency has worked closely with producers with activities that involve technical and financial support in requests made to the INPI, in addition to disseminating and training local workers. These actions are properly aligned with the performance of a mediating agent, fulfilling the expectations directed to the fostering agent in obtaining the GI.

Despite the favorable scenario presented, the participation of Sebrae in the only appellation of origin existing in Sergipe (granted to the manufacture of Irish lace in Divina Pastora) did not assure producers significant economic gains from the selling of their products [25]. This may be indicative of a failure in the promotion stage that must be carried out after obtaining the GI, especially in the marketing and development of distribution channels, points provided for in the methodology proposed by Mapa. However, there are still efforts from different sectors to obtain a successful AO in Divina Pastora.

\subsection{Engagement feasibility}

In order to implement and develop GIs, it is essential not to discard the actions of other local and regional agents, since the Brazilian experience itself has shown that the articulation between different institutions is of paramount importance in the process, such as the interaction between the Brazilian Agricultural Research Corporation (Embrapa) and universities [26]. In this sense, taking again the example of Divina Pastora, whose process of obtaining the geographical indication of source had the participation of the National Institute of the Historical and Artistic Heritage (Iphan) and Sebrae [25].

Table 5 describes the different public and private agents involved in GIs for twenty-one Brazilian states. As Figure 2 already exposed, Sebrae was the agent with the most expressive involvement in GIs. With exception of Tocantins, this entity acted in all the states present in Table 5. 
Table 5: Agents involved in different geographical indications of twenty-one Brazilian states.

\begin{tabular}{|c|c|}
\hline Brazilian state & Agent \\
\hline Acre & Embrapa; Mapa; Sebrae \\
\hline Alagoas & Sebrae; Federal University of Alagoas (UFAL) \\
\hline Amazonas & Sebrae; Federal University of Amazonas (UFAM) \\
\hline Bahia & $\begin{array}{l}\text { Association of Coffee Growers in Western Bahia (ABACAFÉ) } \\
\text { Mapa; Sebrae }\end{array}$ \\
\hline Espírito santo & $\begin{array}{l}\text { Association of Goiabeiras Pantry (APG); Association of Socol } \\
\text { Producers (ASSOCOL); Sebrae }\end{array}$ \\
\hline Goiás & Mapa; Sebrae \\
\hline Mato Grosso & Sebrae \\
\hline Mato Grosso do Sul & Sebrae \\
\hline Minas Gerais & $\begin{array}{l}\text { Association of Jabuticaba Derivatives Producers in Sabará } \\
\text { (ASPRODEJAS); Embrapa; Mapa; Sebrae; Federal Institute of } \\
\text { Northern Minas Gerais (IFNMG); Federal University of São } \\
\text { João del-Rei (UFSJ) }\end{array}$ \\
\hline Pará & Sebrae \\
\hline Paraíba & Sebrae \\
\hline Paraná & Sebrae \\
\hline Pernambuco & $\begin{array}{l}\text { Sebrae; Brazilian National Council for Scientific and } \\
\text { Technological Development }(\mathrm{CNPq}) \text {; Embrapa }\end{array}$ \\
\hline Piauí & Sebrae \\
\hline Rio de Janeiro & $\begin{array}{l}\text { Mapa; Sebrae; Technical Assistance and Rural Extension } \\
\text { (EMATER); Embrapa; Paraty City Hall }\end{array}$ \\
\hline Rio Grande do Norte & Sebrae \\
\hline Rio Grande do Sul & $\begin{array}{l}\text { Association of Tanneries Industries of Rio Grande do Sul } \\
\text { (AICSUL); Embrapa; University of Caxias do Sul (UCS) } \\
\text { Federal University of Rio Grande do Sul (UFRGS); Sebrae }\end{array}$ \\
\hline Santa Catarina & Sebrae; Federal University of Santa Catarina (UFSC) \\
\hline São Paulo & $\begin{array}{l}\text { Coffee Council of Mogiana do Pinhal (COCAMPI); Sebrae; } \\
\text { Footwear Industry Trade Union of Franca (SINDIFRANCA) }\end{array}$ \\
\hline Sergipe & $\begin{array}{l}\text { Association for the Development of the Irish Lace from Divina } \\
\text { Pastora (ASDEREN); Sebrae; Iphan }\end{array}$ \\
\hline Tocantins & $\begin{array}{l}\text { Embrapa; University of Brasilia (UNB); Ministry of the } \\
\text { Environment (MMA) }\end{array}$ \\
\hline
\end{tabular}

Source: Adapted from INPI (2020) [22].

Valente et al. (2013) [11] pointed out that many difficulties related to obtaining GIs are due to the long periods required for construction because of the number of existing rules. Even so, different associations performed as agents of mediation and promotion in the search for registration of GIs, such as Association of Socol Producers of Venda Nova do Imigrante (Associação dos Produtores de Socol de Venda Nova do Imigrante - ASSOCOL) and Association of Jabuticaba Derivatives Producers in Sabará (Associação de Produtores de Derivados de Jabuticaba de Sabará ASPRODEJAS).

The process of seeking recognition through IS for the handicraft produced in Santana do São Francisco was assessed as feasible. In addition to the facts presented, another good indicative is that Brazil already has a background in this line but for other regions, such as (i) the artisanal production of clay pots in Goiaberas (Espírito Santo, Brazil) and (ii) the handicraft with golden grass in the Jalapão region (Tocantins, Brazil) [27, 28]. Still, to use a GI in their products, all the artisans involved need to follow the same quality standard established by the same entity, which in 
addition to guaranteeing the quality of the products, will contribute to the increase in their commercialization [29].

Besides, the involvement of universities can complement the activities developed by the other agents, which reinforces the chance of success in obtaining recognition. Although they are not public policymakers, universities have an interdisciplinary range of researchers who have managed to contribute to the strengthening and dissemination of Brazilian GIs and their potential [18], in particular for acting through the Technological Innovation Centers (NIT), which, as provided for in the Innovation Law No. 10,973 [30], has the purpose of managing the institutional innovation policy, being responsible for the management of the intellectual property and encouraging of creations. Table 6 presents a model of suggested stages for building the expected results.

Table 6: Proposed actions to obtain the indication of source in Santana do São Francisco.

\begin{tabular}{|c|c|c|}
\hline Stage & Action & Responsible \\
\hline 1 & $\begin{array}{l}\text { Consolidation of the collective representation of artisans, } \\
\text { becoming formalized as a representative entity of handicrafts } \\
\text { produced in the Santana do São Francisco }\end{array}$ & $\begin{array}{c}\text { Association } \\
\text { of Artisans }\end{array}$ \\
\hline 2 & $\begin{array}{l}\text { Structuring and raising awareness of the actors involved in the } \\
\text { handicraft production chain, registering aspects of the form of } \\
\text { production, and developing the visual identity of the production }\end{array}$ & Sebrae \\
\hline 3 & Formal registration with the INPI & Sebrae \\
\hline 4 & Disclosure to clients and GI promotion actions & Sebrae \\
\hline
\end{tabular}

Source: Authors' own elaboration.

The low economic power of artisans and their precarious organization has been associated with both the low income of the municipality and the low current added value of clay products. This scenario requires an integrated mobilization of public and private entities to act as fomentation agents and guarantors of the GI consolidation process, even though there is still no guarantee from producers to comply with the IS regulations. Despite this, it is reiterated the existence of a set of aspects favorable to obtain the IS in Santana do São Francisco, namely: (i) geographical, historical and cultural characteristics that led to the emergence of the handicraft production pole, (ii) recognition of the region's handicrafts as a manifestation of popular culture, and (iii) presence of agents promoting regional development with previous experiences in geographical indications.

\section{CONCLUSION}

The tradition of clay handicrafts as a reflection of the collective memory, being a symbol of regional identity passed between generations, combined with the availability of an association and recent initiatives to encourage artisanal activity, reinforces the existence of an environment conducive to the mobilization of agents and resources necessary to obtain the IS registration and, therefore, a way to get intellectual protection for clay crafts produced in the Santana do São Francisco region. In this sense, the participation of Sebrae as a mediating and promoting institution has substantial importance since the entity can act in the collective awareness regarding the production and commercialization of products so that everything remains within the aspects regulated by the INPI - a stage that can still count on the participation of the Technological Innovation Nucleus of the Federal University of Sergipe, in addition to other regional institutions. By adding value to ceramic pieces, it is expected the profitable growth of the region's domestic market, strengthening riverine tourism, and protecting and recognizing products throughout the national territory. 


\section{ACKNOWLEDGEMENTS}

The authors acknowledge financial assistance from the Brazilian research funding agencies as CAPES (Coordination for the Improvement of Higher Education Personnel) under Finance Code 001, a Brazilian foundation within the Ministry of Education (MEC), CNPq (National Council for Scientific and Technological Development), a Brazilian foundation associated to the Ministry of Science and Technology (MCT), and FAPITEC/SE (the Foundation of Support to Research and Technological Innovation of the State of Sergipe).

\section{REFERENCES}

1. Profeta A, Balling R, Roosen J. The relevance of origin information at the point of sale. Food Qual Prefer. 2012 Mar;26(1):1-11, doi: 10.1016/J.FOODQUAL.2012.03.001

2. Uchiyama Y, Tanaka Y, Matsuoka H, Kohsaka R. Expectations of residents and tourists of agriculturerelated certification systems: analysis of public perceptions. J Ethn Foods. 2017 May;4(2):110-117, doi: 10.1016/J.JEF.2017.05.003

3. Bryla P. The impact of obtaining a European quality sign on origin food producers. Qual Assur Saf Crops Foods. 2018 May;10(2):155-164, doi: 10.3920/QAS2017.1189

4. Belletti G, Marescotti, A, Touzard, JM. Geographical indications, public goods, and sustainable development: the roles of actors' strategies and public policies. World Dev. 2017 Oct;98:45-57, doi: 10.1016/j.worlddev.2015.05.004

5. Meloni G, Swinnen J. Trade and terroir. The political economy of the world's first geographical indications. Food Pol. 2018 Dec;81:1-20, doi: 10.1016/J.FOODPOL.2018.10.003

6. Cei L, Defrancesco E, Stefani G. From geographical indications to rural development: a review of the economic effects of European Union policy. Sustainability. 2018 Oct;10(10):3745, doi: 10.3390/su10103745

7. Brazil. Lei $\mathrm{n}^{\circ}$ 9.279, de 14 de maio de 1996. Regula direitos e obrigações relativos à propriedade industrial. Diário Oficial da União. 1996 May 15;(93 Seção 1):8353. Available from: http://www.planalto.gov.br/ccivil_03/Leis/L9279.htm

8. Braz il. Lei ${ }^{\circ} 5.648$, de 11 de dezembro de 1970. Cria o Instituto Nacional da Propriedade Industrial e dá outras providências. Diário Oficial da União. 1970 Dec 14;(Seção 1):10577. Available from: http://www.planalto.gov.br/ccivil_03/Leis/L5648.htm

9. Maiorki GJ, Dallabrida VR, Maiorki GJ, Dallabrida VR. A indicação geográfica de produtos: um estudo sobre sua contribuição econômica no desenvolvimento territorial. Interações (Campo Grande). 2015 Jan/Jun;16(1):13-25, doi: 10.1590/151870122015101

10. WIPO. Geographical indications: an introduction. Geneva $(\mathrm{CH})$ : World Intellectual Property Organization; 2017. 44 p.

11. Valente MER, Perez R, Fernandes LRRMV. O processo de reconhecimento das indicações geográficas de alimentos e bebidas brasileiras: regulamento de uso, delimitação da área e diferenciação do produto. Cienc Rural. 2013 Jul;43(7):1330-1336, doi: 10.1590/S0103-84782013005000076

12. IBGE: Instituto Brasileiro de Geografia e Estatística. Cidades@ - Santana do São Francisco/SE [Internet]; c2017 [updated 2020 Jun 25; cited 2021 Feb 17]. Available from: https://cidades.ibge.gov.br/brasil/se/santana-do-sao-francisco/panorama

13. Sai Deepak J. Protection of traditional handicrafts under Indian intellectual property laws. J Intellec Prop Rights. 2008 May;13(3):197-207.

14. Halbwcahs M. A memória coletiva. São Paulo (SP): Vértice/Revista dos Tribunais; 1990. 190 p.

15. Haesbaert R. Des-territorialização e identidade: a rede "gaúcha" no Nordeste. Niterói (RJ): EDUFF; 1997. $293 \mathrm{p}$.

16. Calliari MA, Buainain AM, Carvalho SMP, Chamas CI, Salles-Filho SLM, Silveira JMFJ. Proteção às indicações geográficas: a experiência brasileira. In: Proceedings of the XII Seminario LatinoIberoamericano de Gestión Tecnológica - ALTEC; 2007 Sep 26-28; Buenos Aires, AR. Buenos Aires (AR): ALTEC; 2007.

17. Tashiro A, Uchiyama Y, Kohsaka R. Internal processes of Geographical Indication and their effects: an evaluation framework for geographical indication applicants in Japan. J Ethn Foods. 2018 Sep;5(3):202210, doi: 10.1016/J.JEF.2018.07.004

18. Pellin V. Indicações geográficas e desenvolvimento regional no Brasil: a atuação dos principais atores e suas metodologias de trabalho. Interações (Campo Grande). 2018 Jan/Mar;20(1):63-78, doi: 10.20435/inter.v20i1.1792 
19. Mendonça, AVM. Visões do passado e do presente na cerâmica morfose de Carrapicho. In: Proceedings of the XXV Congresso Brasileiro de Ciências da Comunicação; 2002 Sep 1-5; Salvador, BA. São Paulo (SP): INTERCOM - Sociedade Brasileira de Estudos Interdisciplinares da Comunicação; 2002. Available from: http://www.portcom.intercom.org.br/pdfs/70205170231274870619750774409298043958.pdf

20. Gramacho APC, Sá NSC, Souza RCA. O artesanato da região do Baixo São Francisco: suas características, níveis de organização e geração de renda. Rev Desenvolv Econ. 2017 Dec;115-142, doi: 10.21452/rde.v3nesp. 5384

21. Matos SMS, Melo ROC. Políticas públicas de desenvolvimento local: o caso do arranjo produtivo de cerâmica artesanal do município de Santana do São Francisco-SE. Rev ABET. 2007 Jan/Jun;7(1):133159.

22. INPI: Instituto Nacional de Propriedade Industrial. Pedidos de indicação geográfica no Brasil [Internet]. Governo Federal [Internet]; 2015 Jul 6 [updated 2021 Feb 17; cited 2020 Jun 20]. Available from: http://www.inpi.gov.br/menu-servicos/indicacao-geografica/pedidos-de-indicacao-geografica-no-brasil

23. Rezende AA. Indicação Geográfica: uma via para o crescimento econômico para Nazaré das Farinhas e Maragogipinho, Bahia. Rev Parana Desenvolv. 2015 Jan/Jun;38(132):55-76.

24. Vieira CP. As Indicações Geográficas como estratégia para fortalecer o território: o caso da Indicação de Procedência dos Vales da Uva Goethe. Desenvolv Quest. 2015 Jan;13(30):155-174, doi: 10.21527/22376453.2015.30.155-174

25. Santos AA, De-Bortoli R. Impactos da indicação geográfica sob a ótica do artesão. Rev INGI. 2018 Sep;2(3):139-154.

26. Medeiros ML, Passador JL. Indicações Geográficas e Turismo: possibilidades no contexto brasileiro. Perspec Contemp. 2015 Sep/Dec;10(3):56-79.

27. Lima TLM, Dantas HTA, Costa LVM, Guimarães PBV. A indicação geográfica como alternativa para o desenvolvimento regional: o caso das panelas de barro de Goiabeiras. Cad Prospecção. 2015 Mar;8(1):169-173, doi: 10.9771/s.cprosp.2015.001.019

28. Silva LP, Rodrigues W. A indicação geográfica dos artesanatos em capim dourado da região do Jalapão do estado do Tocantins sob o enfoque dos princípios da boa governança dos commom-pool-resource. Rev Bras Gest Desenvolv Reg. 2017 Sep/Dec;13(3):3-25.

29. Nascimento JS, Fialho AS, Nunes GS, Bandeira MGA. Indicações geográficas: agregação de valor aos produtos brasileiros e maranhenses. Rev GEINTEC. 2012;2(4):353-364, doi: 10.7198/geintec.v2i4.53

30. Brazil. Lei ${ }^{\circ} 10.973$, de 02 de dezembro de 2004. Dispõe sobre incentivos à inovação e à pesquisa científica e tecnológica no ambiente produtivo e dá outras providências. Diário Oficial da União. 2004 Dec 03;(Seção 1):2. Available from: http://www.planalto.gov.br/ccivil_03/_ato20042006/2004/lei/110.973.htm 